\title{
A mão de obra penal
}

\author{
Candido Motta \\ Conferência realizada no Salão do Auto- \\ móvel Club do Rio de Janeiro, por ocasião do \\ Congresso Penitenciário, em Julho de 1930.
}

Sr. Presidente.

Exmas. Senhoras.

Meus Senhores.

Não tendo tido prévio conhecimento do programa dêste Congresso, que só me chegou às mãos no dia da minha partida para esta Capital, e não querendo o deixar de para aquí trazer uma contribuição mínima que fôsse, para corresponder assim à gentileza do convite e à honra da delegação, procurei pôr em ordem, na medida do possivel, alguns velhos estudos cuja exposição me animo a crer (devido talvez àquele demasiado otimismo que VoltaIRe personificou no seu "Cândido") não será de todo desagradável ao tão seleto auditório que me honra e tanto me penhora com a sua preciosa atenção.

Quando, em 1897, instado pelo meu bom e saudoso amigo Dr. Severino Freitas, para disputar em concurso a cadeira de Direito Penal, que ainda hoje ocupo na velha e sempre gloriosa Faculdade de Direito de S. Paulo, oferecí a minha dissertação sôbre a classificação dos criminosos, 
fi-la acompanhar das proposições regulamentares entre as quais figurava a seguinte, referente ao regime penitenciário:

"O melhor emprêgo da mão de obra dos condenados é nas secções móveis"

A gênese de tal proposição, que aliás passou em branca, nuvem, encontra-se na profunda mágua senão no sentimento de revolta que me causava, ao tempo, o regime das nossas prisões; e na observação quotidiana dos fatos lamentáveis de que eram elas tristíssimo cenário.

Promotor Público da Capital, tive por mais de uma vez, oportunidade de levar ao Procurador Geral do Estado o meu vivo e indignado protesto.

Dizia eu então:

"Cadeia Pública" - E' êste um dos estabelecimentos que maior atenção deve merecer aos poderes públicos, pois que não está de acôrdo com os fins a que é destinado, nem é compativel com a higiene requerida por estabelecimento desta natureza. Edifício sólidamente construido num dos bairros mais apraziveis desta Capital, é todavia, de insuficientes proporções, atento o número sempre crescente de detidos. Tem apenas nove compartimentos e a enfermaria.

Cada um dêstes compartimentos contou diàriamente, durante o corrente ano, uma média não inferior a cincoenta detidos. A aglomeração é portanto, extraordinária, e, justamente por isso, é que o ar que lá se respira é pestilento, infecto..

Se a Cadeia fôsse destinada ùnicamente á prisão preventiva o mal não seria tão grande, mas, não: os pronunciados alí aguardam julgamento, que nem sempre poderá ter lugar em tempo conveniente; e os condenados a penas menores cumprem-nas ali mesmo. Ademais, tirando as mulheres, que têm prisão à parte, não há distinção alguma entre os adultos e menores. Desde Novembro do ano passado esteve na prisão em comum um menor de 14 anos, que só foi julgado em Julho do corrente ano! 
Em Outubro, visitando aquele estabelecimento, encontrei numa das prisões em que se achavam CENTO E TANTOS ébrios, desordeiros e vagabundos, DOZE MENORES de 14 anos, que alí jà se encontravam havia muitos dias.

Encarada por outro lado a Cadeia desta Capital oferece grandes perigos para o moral dos presos. Ali reune-se toda classe de gente, toda espécie de bandidos, toda sorte de viciosos e facinoras e, como a lei é igual para todos, todo indivíduo que, por uma infelicidade qualquer, cometer uma falta punivel, ou que por simples suspeita cair nas malhas da polícia, não poderá, fugir ao pernicioso contágio dos seus detidos.

O regime das nossas prisões tem sido muito descurado; e não se nota movimento algum no sentido do seu melhoramento, principalmente no que diz respeito à prisão preventiva. $\mathrm{O}$ indivíduo que for preso por suspeita de um crime, ou mesmo, os criminosos confessos não devem ser colocados numa prisão em comum. Além de ser aviltante é um constante perigo.

$\mathrm{E}^{\prime}$ interessante observar, como já temos feito, indivíduos ignorantes, completamente boçais, incapazes de arquitetar a mais leve defesa no inquérito policial, e muitas vezes no sumário de culpa - desenvolverem-se no plenário, defenderem-se com habilidade, respondendo todas as perguntas e objeções, com grande pasmo dos que os conheceram antes. E' muito conhecido nesta Capital o caso do célebre "Dr. Anisio", um pretinho gatuno, que, no júri, recusou um defensor nomeado ad hoc, e defendeu-se a si próprio, argumentando com certa habilidade com as disposições da lei e opiniões de criminalistas pátrios e estrangeiros.

Passando á Penitenciária, construida nos fundos da Cadeia, sob a inspiração do sistema radiado, e onde só a paternal bondade do saudoso Dr. Manoel Dias de Toledo poderia realizar milagres, não lograva eu colher melhores inspirações quanto à possível eficácia das penas. E por isso, eu dizia: "O espírito filantrópico das sociedades modernas tem determinado um acurado estudo dos sistemas de encar- 
ceramento dos criminosos e um sério movimento no sentido de suavizar a sorte dêstes, visando o duplo fim da sua completa regeneração e da conservação da ordem social. A êsse movimento, manifestação expressiva do sentimento evolutivo do altruismo, não tem sido estranho o nosso Estado. Ainda, há pouco, pelo Dr. Bernadino de Campos foi nomeada uma Comissão para estudar o assunto.

"Desde que a observação e a experiência foram empregadas como método no estudo da criminalidade chegou-se ao resultado inegável, positivo, em que pése ao misoneismo dos nossos escolásticos, de que nem todos os criminosos são suscetíveis de regeneração; e isto porque grande parte dêles é levada à prática do crime pela ausência absoluta e hereditária do senso moral e pelos defeitos da sua organização psico-fisiológica.

"A conclusão a tirar-se é que o encarceramento penitenciário é de uma relatividade á toda prova, ocupando UM PLANO INFERIOR nos sistemas de repressão penal. Por melhores que sejam, portanto, as intenções do Sr. Dr. Presidente do Estado, e por mais perfeito que seja o trabalho da distinta Comissão, tudo será sem grande alcance porque parte de um principio errôneo da escola correcionalista, contra o qual se levanta o número sempre crescente dos reincidentes estrangeiros, a despeito de todas as reformas e melhoramentos nas prisões"

Que impressão causavam os condenados aos visitantes? De profunda tristeza. Não podiam, entretanto, ser melhor tratados. A alimentação era boa, farta, feita com esmêro e gêneros de primeira qualidade. As oficinas grandes, bem arejadas; o vestiárịo apropriado às estações. Estado sanitário ótimo; mas as fisionomias eram tristes. Tipos macilentos, pálidos, emagrecidos, de olhar encovado, em harmonia com as faces; indiferentes quando não deixavam transparecer uns láivos die desdém, ou ódio ao visitante curioso. Davam enfim, a impressão, não de homens, mas de bonecos de engonso, e que tornava ainda mais sensivel pelo absoluto silêncio auburniano. Múmias. que me traziam ao espírito 
as páginas imortais de "Souvenir de la maison des morts" do insigne DOSTOLEWHSKY.

Que esperar de tal gente? A grande maioria teria que afrontar os olhares curiosos e desconfiados dos patrões a que se apresentassem pedindo trabalho, e de responder às naturalíssimas perguntas:

Donde vem? Quem foi seu patrão?

Acabo de cumprir pena na Penitenciária.

Eh!. Ahn!. . Está bem. Mas eu agora não preciso. tenho já muita gente.

Que remédio? Mudar de cara, mudar de terra, mudar de nome, transformar-se, enfim. Mas em que sentido? Num eterno revoltado contra a sociedade que o puniu e ora o desprezava cruelmente!

Eis aí!

Tudo isso me passava pelo espírito de moço em constante revolta, e me levava a investigar se o engenho humano, tão fértil, não teria ainda encontrado um remédio eficaz para o caso, uma solução para êsse problema que no momento à minha inexperiência de moço se afigurou insolúvel.

Fui aos livros; recorri às informações do estrangeiro e, certo dia, jubiloso pude exclamar o meu Eureka. Achei!

Não mais temos a pena de prisão perpétua. Os egressos da penitenciária, têm que voltar ao convívio social; mas. a vida das prisões os deformou.

Mesmo em estabelecimentos modelares como o nosso, o presídio do Carandirú, onde a apaixonada dedicação do Dr. Franklim Piza tanto concorre para o bom êxito, não se podem obviar aqueles inconvenientes.

Alí trabalha-se já ao ar livre; mas é a simples jardinagem que, se faz bem à saúde, distrái o espírito, limita, por sua vez, as fôrças, não as desenvolve, não garante um futuro compensador.

$\mathrm{Na}$ penitenciária do Estado, não gozam os presos, tão pouco, e felizmente, das facilidades da Penitenciária de Cettigne, onde vivem de portas e janelas abertas; podendo passear livremente nos terraços ou nos páteos, em pequenos 
grupos, jogando e fumando; um paraíso enfim, de onde o meu informante desafiava que qualquer dêles pretendesse evadir-se. Mas ainda não satisfaz.

A solução do grave problema está mesmo no trabalho ao ar livre; porém, não dentro das muralhas de um presídio, seja êle belo e confortável como o nosso - embora sem horizontes; está sim, no trabalho braçal, pesado embora, mas que retempera as forças físicas, desenvolve a robustez, desanuvia o espírito, garante a saúde.

Colônias agrícolas? Não. Aos governos previdentes não pode convir tal solução, a menos que tais colônias tenham uma extensão territorial como a do nosso próprio pais, em que os colonos se afundem e se misturem com os nativos e nunca mais deixem falar de si como aquele celebre autor do "Conto do estoicismo" de que nos dá notícia o nosso Dr. Souza Bandeira em seu relatório sôbre "Fernando de de Noronha", e que por esta forma gemía as suas dores e alçava o seu protesto:

"Da mais estulta tirania afronto

Dura opressão.

Ante a polé, o pelourinho infame. Não tremi, não!

Bruta cadeia, em gargalheira ao solo

Fere-me o ombro.

Oh! Vis esbirros! de tão pouco ainda

Me não assombro.

Lancem-me aos pés inda os grilhôes d'escravo.

Recebo-os, louco!

Levem-me a rastos aos olhais de um cepo.

Ainda é pouco!

Eis tirano! Apavorou-te o forte, altivo ao jugo!

Dize-me agora se é maior o martir ou se o verdugo"

Não sendo, porém, assim, poderiamos também ver surgir entre nós "um país de criminosos-natos", como aquele "piccolo commune de Artena" de que nos fala Scepio Sighele, no "Archivio de Psychiatria", de 1890, uma vez que as famílias dos condenados lá se cruzam e se reproduzem. 
"Artena, diz Sighele, surge quasi que como um oasis selvagem no meio de uma população civilizada, e o extraordinário número dos seus crimes parecia inverosímil e permaneceria inexplicável, se não se recorresse à lei da hereditariedade, e se não se pensasse que talvez - como todo o veneno mesmo produzindo os seus efeitos em todas as partes do organismo, aféta entretanto especialmente um órgão sôbre o qual exerce aquilo que se costuma chamar a sua ação principal - assim também o micróbio do crime - veneno do organismo social - invadindo todas as partes dêste organismo, exerce, porém mais intensamente em alguns lugares a sua influência deletéria".

Já, em 7 de Maio de 1557, o Papa Paulo IV, expediu do Castelo Montefortino (Artena) o seguinte edito:

" $E$ ' notorio e manifesto ad ogni persona, da revolti et molti armi in qua la suabas vita universale dè li huomini de Montefortino in publico et in privato, et in quanto sempre siano stati ribelli et inimici de li sommi Pontifici, et di Santa Chiesa, prendanno li convicini sudditi fideli, rubanno assassinando, fortificando il Castello, recevendo soldati inimici per loro aiuto e diffesa con fraude et inganni sotto colore de obedicenza, svaligiando, facendo prigioni et ammazzando e soldati di Sua Santità, per il che non essendo si grande pena, quale in publico et in privato non meritono maggiore, et acciochè il loro castigo sia execupio a tuti. N. S. re Paulo per divina Providenza Papa Quarto, volenno provedere alla quieta da queste paezi, et servitio dela Santa Sede, acciochè questo Castello de Montefortino non abbia ad esser piú nido et rècepto da tricti ladroni et rebelli. Ha determinato totalmente si scarchi et ruini, et che del tucto il territorio rebellione se ne piglia il possesso par la reverenda Camara Apostolica come si è facto, et di tucti gli huomini de decto Castello già nominato 
Montefortina se badiscono della vita, et a far questo ha dato a noi ampia auctoritá de poder ordinare et commandare a tucti i Baroni feudatari; soldati a piede et a cavallo, communità e particulari, et volenno. Non eseguire la mente de sua Beat ne per il presente publico bando si dichiarono tucti le decti huomini del gia Montefortino come notori ribelli esserno incorsi nella pena del ultimo suplicio, et de confiscatione de tucti loro beni et che sia lecito ad ogni persona, senza pena de offenderli, et si commanda expressamente et se prohibisce a tucti etc. etc. Assign. Desiderio Guidone, da Ascoli, Commissario".

A extrema providência, como diz Sighele, posta em execução por Paulo IV:

"de badire della vita tutti gli uomini di Montefortino e di dar facoltà ao ogni persona d'ucciderli"

não conseguiu extirpar o mal.: De geração em geração, nem os rigores de uma legislação de ferro, puderam contra a indole dos habitantes do desventurado país. E a crônica judiciária continua a ser:

“l'assassinio vendicato coll'assassinio la testimonianza contra gli assassini punita ancora col assasinio, l'odio gratuito ed esugerato, la più futile emulazione fra individui od famiglie, il più lieve sgarbo o dispetto fra vicino causa determinanti ancora - l'assassinio".

Na sentença de 2 de Julho de 1872, lê-se:

"Em Montefortino, su qule e di Villetri, classica terra di misfatti dove la vendetta è un barbaro diletro persino tra le persone de la stesa famiglia, $i$ delitti, correndo l'ultimo ventennio, acquistarano uno spaventoso incremento. Estermini di intere 
cassate e orribili eccidi e grassazioni ed estorsioni $e$ incendi, e in pieno meriggi nel paese e nelle vicine strade publiche e private. Fosse paura dell'altrui vendetta, o fosse desiderio di vendicarsi loro stessi, tacevano gli offesi, tacevano e testimoni o mentivono, intanto l'impunitá si faceva strada nel sangue e nell rapina. Una associazione di uomini perversi figli di grassatori e di omicidi che morivano asse stessi nelle galere o su i patiboli, pretendevano in Montefortino alla privativa, al monopolio ditanti e si orribili misfatti".

Ao passo que toda a Itália nos periodos de 1853 e 1872 e de 1873 a 1885 apresentava uma média de homicídios e assassinatos de 9,38 por cada 100.000 habitantes, a provincia romana de 25,40 , Artena, tinha uma média de 52,50 no primeiro período e de 61,50 no segundo.

Mas, pergunta Sighele, quais são as causas que fazem de Artena, o pais dos criminosos ou, como diria talvez com feliz expressão H. Joly, um verdadeiro foco de criminalidade espontânea?. A causa mais forte, responde, e mais- evi đênte é a HEREDITARIEDADE. Como, em certos lugares ou devido ao mau clima ou por outras infelizes condições de ambiente, os habitantes trazem consigo, de geração em geração, uma moléstia; assim em Artena, uma parte dos habitantes transmite, de geração em geração, a tendência para o crime.

O Dr. SLOCKER, de Berlim, nos dá notícia de uma família cujo tronco era constituido por irmãs, uma das quais morreu em 1826. A sua descendência consta de 834 pessoas, de 709 das quais foi feita uma acurada história. Destas 709 existiam 106 filhos ilegitimos, 164 prostitutas, 142 mendigos, 64 asilados, 76 criminosos, e 17 daquela espécie a que pertencia.

"Colui che la Ghisala bella conduce a far la voglia de Marchese"

"Via ruffian!" 
Eis ai, em suma, quanto se pode esperar de uma colônia exclusivamente penal!

Consultemos, porém, ainda o exemplo de outros paises; ouçamos os grandes mestres.

No Congreasso Penitenciário; de Darmstadit, (1889) M. RUKSTRATT, diretor da Penitenciária de Vechta, embora reconhecesse as graves dificuldades que apresenta o trabalho exterior sob o ponto de vista da boa execução da pena, nêle via grandes vantagens econômicas; mas entendia que êsse trabalho deveria ser reservado aos condenados a penas de longa duração, escolhidos individualmente em razão do seu caráter, capazes de resistir aos inconvenientes do trabalho em comum.

M. DEYSER, diretor em "Deux-Ponts", é decidido partidário do trabalho agrícola, pois que nêle vê quatro vantagens capitais:

$1 .^{\circ}$, melhor higiene para o condenado pela benéfica influência do ar livre;

2. ${ }^{\circ}$, facilidade de manter a disciplina só pelo receio de voltar para a prisão;

3. ${ }^{\circ}$, fácil colocação dos liberados, que tenham o hábito de um trabalho sério e que se encontra em 'toda parte;

4. , ocupação prolongada dos presos sem causar reclamação do trabalhador livre.

Podem se aplicar à agricultura os presos de qualquer idade e categoria, sem necessidade de aprendizagem preliminar.

Podem ser reservados suplementos de alimentação ou de bebidas, justificados pela quantidade de força dispendida como encorajamento aos trabalhadores honestos.

Do mesmo sentir é M. MILLENTZ, diretor em Nangard. Ele vê nesse gênero de ocupação o interêsse do Estado e dos própios condenados. $\mathrm{E}^{\prime}$ todavia de parecer que se deve prö̈bir a agricultura aos condenados a penas perpétuas, aos 
reincidentes, aos inclinados a evasão e, em geral, a todos quantos tenham fôrça física ou necessária habilidade manual.

No domínio de Gorrenberg (circulo de Cohuenitz) 36 cơndenados foram empregados cêrca de 3 mêses nas obras do enxugo.

Em Lichtemburg 80 condenados trabalharam durante dois anos em melhorar o leito do Elba, enquanto que outros 80 trabalhavam no reforçamento dos diques.

Na Prússia Oriental, duas secções de condenados trabalharam no enxugo dos pantanos de Seclon e de Augstsernol.

Os presos de "Duas Pontes" terminaram, em 1900, o beneficiamento das charnecas e pantanos de Eifel transformados em excelentes campinas. $O$ estabelecimento de Lichtenau transformou em cultura 240 alqueires de terras e prados. Em Preil, uma turma fornecida pela prisão de Wartemburg era ocupada em retirar a areia impelida contra as primeiras casas da aldeia, especialmente contra a escola.

Em 1895, o Ministro do Interior dirigiu aos presidentes das provincias prussianas uma circular com o fim de autorizar, sob certas condições e em casos estritamente determinados, a aplicação da mão da obra penal nos trabalhos de melhoramento do solo. Os diretores das prisões mostraram-se muito solícitos em aproveitar a permissão e em atender os pedidos dos agricultores.

Em circular de 20 de Novembro de 1899, constata o favor com que êstes receberam a inovação, e nota, no mesmo tempo a feliz influência desta sob o ponto de vista penitenciário. Sòmente os resultados financeiros deixavam, alguma coisa a desejar: era a consequência das despesas de toda natureza, provenientes do transporte e alimentação dos condenados.

Para aliviar tais inconvenientes, o Ministro formou um quadro preciso e detalhado de todas as despesas, que deveriam ficar a cargo dos empresários; e entra em minuciosos detalhes quanto à alimentação, ao vestuário e calçados dos con- 
denados, bem como sôbre o preparo dos lugares destinados à sua instalação.

A fixação do salário é estabelecida sôbre bases cuidadosamente estudadas de modo a assegurar uma renumeração conveniente ao trabalho e a afastar toda causa de prejuizos para o estabelecimento.

Assim, por exemplo: o empresário deve se obrigar a juntar ao salário normal um prêmio de seguro contra os acidentes do trabalho e encarregar-se de todos os emolumentos devidos aos empregados, inspetores, auxiliares, contra-mestres chamados a conduzir os trabalhos.

O caráter meticuloso destas descrições indicava que a administração não estava sòmente resolvida a perseverar em tais experiências, mas que fazia questão de fiscalizar de bem perto os resultados financeiros; e uma vez que prosseguiu é porque tais resultados lhe agradaram.

Foi apenas a titulo excecional que, para os trabalhos de melhoramentos do solo na falta de mão de obra livre ou no caso em que esta não pudesse ser convenientemente aproveitada, êle autorizou a recorrer à mão de obra penal. A circular de 30 de Junho de 1900 aboliu estas restrições e estendeu o emprêgo dos presos aos trabalhos agrícolas de toda a natureza.

Além das prescrições de ordem financeira ou administrativa ela formula ainda certas regras que merecem ser mencionadas.

Assim permite empregar as próprias mulheres nestes trabalhos de cultura, se o lugar fôr bem próximo do estabelecimento em que estejam presas de modo que possam ser para alí conduzidas todas as tardes; mas com a condição de que o transporte se opere, especialmente nas cidades, ao abrigo da curiosidade pública.

Os condenados á prisão só poderão se beneficiar deste regime se já tiverem cumprido, pelo menos, três mêses da sua pena; e os forçados seis mêses, não devendo faltar a uns e outros mais de dois anos para a completa extinção. 
E' recomendada a maior prudência na escolha dos condenados; devendo ser excluidos todos os que forem considerados rebeldes, perigosos ou inclinados à fuga.

o Ministro renova, enfim, de modo imperativo a ordem de separar os condenados dos trabalhadores livres.

Duas novas circulares, de 29 de Março de 1902 e 7 de Julho de 1907, vieram ainda, sôbre dois pontos, completar ou modificar a regulamentação anterior. Daí por diante, nenhum condenado será empregado nos trabalhos externos, se não tiver purgado, pelo menos um ano de sua pena; mas a regra, de que "não lhe reste mais de dois anos" a cumprir, subsiste.

Além disso, todos aqueles que, depois da sua libertação, sofrerem dentro dos três anos seguintes uma nova condenação, não poderão mais, salvo casos excecionáis e justificados, ser novamente empregados em trabalhos de campo.

Em uma outra ordem de idéias, uma dessas circulares determina que o conjunto das indenizações concedidas em remuneração ao trabalho dos condenados e ao estabelecimento de que êles dependem, não deve ser inferior de $3 / 4$ dos salários que, segundo os usos do país, são pagos aos operários livres.

Este detalhe, é, na opinião de M. C. DE Monicault, um indício de espírito de previdência financeira e econômica que tem, na Alemanha, inspirado estas experiências.

0 Govêrno obedeceu ao pensamento de reduzir as despesas do seu serviço penitenciário e mais ainda, talvez, ao de proteger os interêsses da grande lavoura. Animado pela satisfação que testemunharam os representantes desta, êle se mostrou interessado em desenvolver ainda mais a experiência. Nesse mesmo ano, uma conferência de altos funcionários se realizou, em Maio, em Hoenigsberg.

O seu programa era de informar dos melhores meios de satisfazer aos proprietários alemães de Leste, que, na previsão de uma falta de braços, devido à agitação polaca, solicitavam do Govêrno fôsse posta à sua disposição a mão de obra penal. 
O Ministro de Justiça tinha enviado delegados a esta Conferência e, à vista do relatório dos mesmos, fez publicar um decreto cujas disposições tendem a alargar o campo de uma reforma, que corresponda a uma das mais vivas preocupações do poder público.

A Alemanha, apesar do aumento da sua população, sofria com a escassez da mão de obra agrícola; e os seus homens d'Estado trataram para logo de conjurar o perigo, lançando mão de providências oportunas.

Na Argélia, diz Luiz Paol, é esta uma questão que apaixona muitos espíritos, há já muitos anos.

Todos os governadores gerais, que alí se têm sucedido, mantiveram em seus programas de colonização êste voto expresso, por várias vezes, pelas diversas corporações eletivas locais.

O emprêgo da mão de obra penal tornou-se uma fórma mui agradável aos ouvidos de pessoas que gostam de dar a dura opinião sôbre os negócios da colônia.

Nunca esta proposição tomou corpo de modo a poder ser discutida conforme as regras de método experimental.

Há três anos, entretanto, tímidos ensáios foram realizados nos departamentos algerianos; e as delegações financeiras, criadas por um Decreto de 23 de Agosto de 1898, tiveram que se pronunciar sôbre o assunto em sua sessão de Novembro de 1899.

0 Govêrno dirigiu, naquele ano, um questionário muito preciso, sendo que, em relação à mão de obra penal, que mais nos interessa assim procedeu:

Após um exame dos diferentes dados do problema (efetivos dos diferentes estabelecimentos, negócios concluidos pelo serviço das prisões com os empreiteiros gerais ou particulares, concurrência feita à mão livre, condições de trabalho na Argélia, modo de execução dêsses trabalhos, organização das turmas de sentenciados, despesas 'etc.) a Comissão nomeada para procurar os meios de utilizar a mão de obra penal nos trabalhos que o Estado fez executar na 
Argélia concluiu que havia um interêsse de primeira ordem em empregar os presos em certos trabalhos, tais como derrubadas de matas, aberturas de estrada, saneamento e expurgo dos pantanos, etc.

Tendo o Ministro do Interior apresentado certas objeções às propostas feitas pelo Governador Geral, a Comissão chamada a examiná-las julgou que para se inteirar exatamente das vantagens ou inconvenientes do emprêgo da mão de obra penal era necessário proceder a algumas experiências; e, com êsse fim, foram feitas duas, uma em Lavacher, centro em via de criação no departamento de Alger, e outra em Laervix, centro criado no departamento de constantina.

O trabalho consistia em desbravar o terreno e adaptá-lo por um trabalho manual, isto é, a ancinhos, em uma profundidade apenas de $0 \mathrm{~m}, 25$. O grupo de Lavacher foi formado por uma turma de 200 condenados da Penitenciária de Bourrnaghia, que diretamente utiliza o trabalho dos presos.

Afim de tornar a experiência mais concludente, o território do Lavacher foi dividido em duas partes eqüivalentes para serem desbravadas, uma pelos sentenciados e a outra por uma emprêsa particular, após uma adjudicação.

Em Lacroix, os trabalhos foram confiados a uma turma de 200 condenados da Casa Central de Lambese, afim de efetivar uma experência com o sistema da emprêsa que dirige êste estabelecimento.

A despesa elevou-se em 15 de Outubro de 1899, para o centro de Lavancher, a 93.310 frs., dos quais 72.480 frs. pela mão de obra penal.

Os dias do trabalho feito pelos presos foram empregados, parte em casas particulares, nos trabalhos agrícolas e derrubadas, aterros e na maior parte em serviço por conta da emprêsa do interior das prisões.

Procurou-se substituir êsses trabalhos de interêsse particular por trabalhos de interêsse público, tais como colonização, construção de estradas, vias férreas, etc. Esta substituição pode-se justificar por muitas considerações. 
Em primeiro lugar, a mão de obra penal, apresentando um certo caráter de interêsse público, parece que deve ser, de preferência empregada no interêsse público e não no interêsse particular.

Por outro lado a organização de terrenos penitenciários sufficientes para a execução dos trabalhos penosos nas regiões insalubres ou muito distantes dos oentros populosos, oferece assinaladas vantagens sôbre as turmas particulares, quer quanto à disciplina, quer quanto à higiene, à divisão e regularidade do trabalho e à despesa.

Ora, E' PRECISAMENTE NOS TRABALHOS DESTA CATEGORIA QUE A MÃO DE OBRA PENITENCIARIA pode ser empregada sem fazer concorrência aos operários livres...

Quanto ao concurso da Administração, êle está inteiramente assegurado para toda a reforma, que tenha por fim - RESERVAR OS TRABALHOS INTERIORES DAS PRISÕES AOS ENFERMOS E INCAPAZES, afim de empregar os sentenciados válidos de uma maneira mais útil á sociedade, mais lucrativa para êles, e permitindo utilizar todas as suas aptidões e facilitar a sua reintegração no convívio social.

Será preciso, pergunta M. SAbatier, diretor dos serviços penitenciários na Argélia, retirar esta mão de obra aos empresários, que atualmente a empregam, para aplicá-la nos trabalhos públicos?

Sim, por três razões: é justo que um bem público, tal como a mão de obra penal, seja utilizado nas obras públicas e não na construção de fortunas particulares; o Estado tomará em bem melhor consideração que os particulares êsse elemento para assegurar a reclassificação social e a moralização dos presos; os chantiers públicos oferecerão uma permanência e uma regularidade que os protegerá contra a cessação do trabalho.

Admitido isso, a que trabalhos deve ser ela reservada? Deve-se distinguir êsse trabalho em duas classes: os que a mão de obra livre pode efetuar em condições normais, e 
aqueles aos quais teve que se renunciar, em razão dos preços excessivos exigidos por ela.

Pensa Sabatien que sie deve reservar a mão de obra penal para esta última natureza de trabalhos, e para isso apresenta dois motivos:

1. Conquanto, considerando as cifras para todo território, a concorrência de mão de obra penal à mão de obra livre seja um fenômeno pouco apreciável, êle assim não será si se examinarem os fatos em uma localidade onde estiver organizado um grande chantier.

Em Ameur-el-Ain, trabalhavam, então, na casa do mesmo proprietário, cerca de 200 senienciados civis e militares. Não resta dúvida que o mercado da mão de obra ficou perturbado por este acúmulo de trabalhadores importados para esta pequena região.

2. A mão de obra penal, cujo rendimento tanto em qualidade como em quantidade é inferior $1 / 5$ ao dos trabalhadores livres - menor de $40 \%$ entre os Europeus, de $10 \%$ entre os cabilas ou entre os arabes - torna-se quanto ao preço, quasi igual à mão de obra livre. A econômia realizada pelos arrendatários dos chantiers jamais excede a 50 centimos por pessoa, e o mais das vezes, não excede a 25.

Para os 500 mil dias suscetiveis de serem utilizados o lucro do Estado não excederia, pois de 200.000 frs. por ano. Não é essa a enorme fonte de benefícios de que se tem falado; mas seria, ao contrário, motivo de reclamações e recriminações, que não tardariam em chamar para a sua causa os próprios corpos eletivos.

Ademais o próprio benefício tornar-se-ia para logo ilusório. Não tardaria, çom efeito, que exigissem do Estado, convertido em arrendatário de homens, sacrifícios para melhoramento re bem estar destes homens, sacrificios que excederiam o ganho esperado e transformariam assim a operação em uma fonte de despesas.

Existem porém trabalhos para os quais a mão de obra livre não é aplicável em razão do seu elevado preço: tais os enxugos dos pantanos para os quais a mão de obra penal 
seria muito indicada, si a lei reservasse tais trabalhos aos condenados a trabalhos forçados perpétuos: tais os trabalhos no Extremo-Sul, que não se podem empreender em razão do preço exagerado a que se eleva pela mão de obra livre. Indico para o caso a mão de obra penal.

Calculei, prossegue M. Sabatier, que para um depósito nas grandes dunas do Sahara a economia realizável, por dia e por pessoa, seria de 5 frs., ou seja 500 mil diárias, dois milhões e quinhentos mil francos. Eis aí a operação.

Por outro lado, o clima é salubre, mas duro, a distância dos depósitos, em um país desconhecido para quasi todos os condenados, e o calor por vezes intenso, deram à pena senı intervenção alguma de homem, o caráter que hoje lhe falta - o de verdadeiro castigo.

M. Donmoy constata que em Lacroix, o trabalho ef'etuado pelos presos deu melhores resultados. Eles de fato, como confessam os colonos, executaram o serviço a razão de 243 frs. o hectare, que teria custado 360 frs. com operários livres. Convém, pois não repelir de modo absoluto o emprêgo desta mão de obra na colonização tanto mais que o lucro realizado pelo desmonte preliminar de uma dezena de hectares de cada concessão produz um auxílio muito eficaz aos colonos do que aquele que resultaria de economias feitas sobre artigos do orçamento aplicáveis aos trabalhos do extremo-Sul.

M. Sabatien explica que se empregou em Lacroix uma mão de obra escolhida, recrutada entre os individuos condenados a penas longas, e tendo tempo para se regenerar nos depósitos, com os trabalhos que dêles se exigem. Duzentos tinham sido escolhidos num grupo de 1.100. Tratava-se, com efeito, de uma experiềncia que se desejava coroada de êxito. Mas convêm retirar êste elemento de sucesso, que não se encontra em outros depósitos. Disseram, prossegue, que eu faria com 240 frs. o que custaria 340 com a mão de obra livre. Tal cálculo não seria exato em toda parte pelas razões ja referidas. Persisto, pois, na crença de que os presos devem ser, sobretudo, empregados nas regiões 
afastadas do Sul algeriano. Os colonos, afinal, não verão com maus olhos esta mão de obra empregada ao longo em trabalhos tais como CONSTRUÇÃO DE ESTRADAS etc., pois não ignoram que tais trabalhos são de utilidade geral e a todos aproveitam.

Além disso, M. Sabatier não se opunha a que estas experiências fôssem continuadas no Tell. A MãO DE OBRA PENAL tinha sido, até então, garantida a empresários; mas depois de algum tempo, à medida que se terminavam e se renovavam os negocios, o Estado reservava para si o direito de êle próprio, à medida das necessidades, empregar um certo número de sentenciados, e, assim, em Lambese, dispunha de 200 condenados e em Alger, da totalidade.

Como conclusão desta ̧̧ longa e interessante discussão perante a Sociedade Geral das Prisões de París, e em que tomaram parte Ms. Aymes, Pay'ereinhoff e P. Rivaille, a delegação dos colonos externou o voto seguinte:

“A delegação emite o voto de que a mão de obra penal seja aplicada em todos os trabalhos de utilidade pública, neles compreendidos os da colonização, e não seja de modo algum empregada na cultura de terras já valorizadas e dependentes de estabelecimentos penitenciários.

M. Berard deu o seguinte parecier:

“A questão da mão de obra penal, que figura na ordem do dia dos nossos trabalhos, já pela própria Administração e pelos nossos Concelhos Gerais. Foram propostas duas soluções diferentes; foi feito um certo número de experiências e, finalmente, se desenha uma corrente nitidamente em favor do emprêgo da mão de obra penal nos trabalhos de utilidade pública. Acabou-se por compreender que esta mão de obra era assim muito prejudicial à mão de obra livre; $\mathrm{e}$, por outro lado, chegou-se a reconhecer que a solução mais vantajosa a adotar, sob o ponto de vista moral como sob o material e financeiro, era a organização de ranchos disciplinares em todos aqueles pontos 'em que houver falta de operários civis e particularmente nas regiões afastadas onde tudo ainda se acha por fazer. Além disso, a mão de obra penal 
é uma fôrça que só tem sido parcialmente utilizada, pois 2/5 dos sertenciados ficam ordinàriamente ociosos. Parece indicado abandonar o processo até aquí seguido, isto é, não mais fazer trabalhar os condenados em estabelecimentos particulares nem nas prisões por conta de empresários, e os destinar exclusivamente à execução de trabalhos de colonização, tais como a criação de núcleos, construção de caminhos, barragens, estradas de ferro e enxugo dos charcos.

Numa das sessões do Concelho Superior das prisões o mesmo M. BERARD propôs o seguinte voto:

"O abaixo assinado, considerando que a construção das estradas de ferro e, com a construção de barreiras, mais imperiosa e imediata que as estradas de ferro de penetração no Sul, juntando às suas vantagens econômicas mais a de garantir a segurança de Tell, e que assim elas se impõem sob o duplo ponto de vista; considerando que a mão de obra penal, por mais afastados que sejam os chantiers em que é utilizada, não implica mais do que um pequeno aumento de despesas, e que, porisso ela se recomenda particularmente para os trabalhos de penetração no Sahara, faz votos para que a mão de obra penal seja, de preferência, empregada na construção das linhas de penetração no Sul, principalmente na de Berronghia a Lagonat"

O relator, M. Bronssais afirma: "o voto do nosso colega reproduz o desejo muitas vezes expresso por nós de uma utilização da mão de obra penal, civil e militar, em trabalhos de utilidade geral, cuja distância, insalubridade e dificuldades de toda espécie afugentam, o mais das vezes a mão de obra livre"

O Greneral Pedoya, comandante da divisão de Argel, estima que os resultados colhidos da mão de obra penal não são maus como pretendem, e que os colonos devem nela encontrar proveito, pois que em toda a parte êles reclamam os condenados militares e a Administração não pode atendê-los.

Na DINAMARCA, o trabalho penitenciário, é em parte, industrial e em parte doméstico. 
Em alguns casos os presos se ocupam de trabalhos de jardinagem e de campo. Na Penitenciária de Konsens, alguns anos atrás, foi experimentado em larga escala e com bom êxito moral e disciplinar, o trabalho de melhoramentos territoriais.

A "Revista de la Discipline Carceraire" de 1897 nos informa que o trabalho mais interessante mais dificil e, ao mesmo tempo, mais notável que até entâo se tinha realizado com a mão de obra dos sentenciados na Austria, foi a retificação do curso do rio Dsava, que com um longo percurso de Pusterthal se lança no Danubio, atravessandio o vale gelado de Rosenthal, perto de Klagenfur.

Essa obra foi realizada durante o rigorosissimo inverno de 1892-93 por uma turma de condenados tirada dos estabelecimentos penais de Morburg e Laibach.

0 empreendimento tentado foi abandonado pelas dificuldades da estação, superiores ás fôrças dos operários, tendo que se realizar durante os mêses mais frios de Dezembro a Março, no meio de tempestades de neve, com o terreno gelado, tão duro como pedra. A despeito de um salário de 5 liras por dia os trabalhadores abandonaram o serviço.

O diretor da Penitenciária de Morburg, o Sr. MarcovIcH, empreendeu êsse trabalho com 180 presos que, em Novembro de 1892, se estabeleceram em Vezeilsdorf sôbre Rosenthal, construindo dois grandes barracões convenientemente aquecidos. A-pesar da nevie que tornava necessário conservar nos barracões grandes fogueiras, a-pesar dos instrumentos de ferro se quebrarem no sólo endurecido, o trabalho caminhou regularmente, e em fins de Março estava concluido.

Nenhum funcionario estava presente ao trabalho e contudo a disciplina se manteve excelente entre os 180 sentenciados, que mostraram uma atividade maravilhosa, e cuja saúde se manteve sempre satisfatória.

Depois, sempre que havia inundações e outros contratempos nas províncias austriacas, os sentenciados, requisita- 
dos por telegrama, eram sem demora remetidos para que com o seu trabalho prestassem os socorros necessários.

Os trabalhos agrícolas tiveram tambem sensivel desenvolvimento. Da Penitenciária de Marburg mandavam-se diáriamente mais de uma centena de sentenciados para os trabalhos de campo e de vinhedos próximos, recebendo preliminarmente, no próprio estabelecimento, a necessária instrução. E isto veiu mais uma vez confirmar como o emprêgo da mão de obra penal nos trabalhos de utilidade pública pode-se tornar mui vantajoso e benéfico.

Parece que na Baviera tem dado bons resultados o emprêgo dos condenados nos trabalhos de melhoramento dos terrenos incultos e paludosos, depois das instruções precisas que, em 1900, expediu o Ministro do Interior e da Justiça.

Os imensos trabalhos em que eram empregados, nos domínios de Bifonte, os condenados do Estabelecimento penal da dita localidade, eram executados de modo irrepreensivel e com a máxima ordem, a não ser de alguns casos isolados como o seguinte, que ocorreu em Lessin:

Uma leva de condenados da Penitenciária de Stolps, enviada aos trabalhos por conta de um particular, conseguiu obter grande quantidade de aguardente, embriagou-se, fez uma algazarra infernal. Intimada a se calar, insurgiu-se, atacou os guardas, jogando-lhes pedras e garrafas. Foi preciso o auxílio da população civil para dominar a sua rebeldia.

ESTADOS UNIDOS - No "Bulletin of the department of Labour", de Washington, número de Dezembro de 1896, encontram-se as seguintes notas sôbre os trabalhos carcerários daquela República em 1895 confrontados com os de 1885:

“Os condenados recolhidos à Penitenciária são empregados especialmentei nas minas de carvão, nas pedreiras, no cultivo dos campos, na abertura de estradas, canais, nas fábricas de ladrilhos, nos ofícios de ferreiros, sapateiros, etc." 
Em ALABAMA os sentenciados podem trabalhar ao ar livre, nas obras públicas. Em ARKANZA dá-se o mesmo, podendo além disso ser-lhes confiada determinada extensão de terras para o necessário trabalho.

Na CALIFORNIA é permitido ao Estado tomar de arrendamento pedreiras para nelas ocupar os condenados, sob a direção de pessoal livre.

Em KANSAS é permitido fazer trabalhar os condenados nas minas de carvão, no arroteamento das terras pertencentes ao Estado, na construção e reparação das estradas. Em KENTUCKY os condenados devem trabalhar dentro do estabelecimento penitenciário, exceto nos casos de obras públicas ou por ocasião de epidemias.

Na LUISIANA, os condenados só podem trabalhar nas obras públicas quando não houver outro trabalho.

No MISSISSIPI, devem trabalhar no interior da penitenciária ou nos terrenos arrendados para aquele fim. Em NEBRASKA admite-se tambem o trabalho externo uma vez que os empresários sejam de reconhecida honestidade e haja nisso interêsse para o Estado. Em NEW-JERSEY podem os condenados trabalhar em serviços agrícolas e industriais. Dá-se o mesmo em NEW-MEXICO, em OKLAHOMA e CAROLINA DO SUL, sendo que em Tennessee são admitidos em trabalhos agrícolas e nas minas de carvão.

E já que falamos dos Estados Unidos não me è possivel deixar de recordar as palavras do nosso ilustre patricio, Dr. José Custodio Alves Lima, numa brilhante conferência aqui realizada no Club de Engenharia, a $10^{\circ}$ de Dezembro de 1911, sôbre a qual a pedido do mesmo, tive que me pronunciar em Março de 1912.

Dizia o Dr. José Cústodio: "Voltando ao assunto primordial, cabe-me dizer de que modo os diferentes Estados daquele país, estão construindo e melhorando as suas estradas. Os americanos estão aproveitando os presos nesse serviço." 
"Na maioria das estradas os presos trabalham com guardas à vista, devidamente armados e municiados. Já no Estado de COLORADO o processo é outro, mais humanitário e econômico."

"O honrado Governador dêsse Estado, Sr. John F. SHAFroth dizia no Congresso das Boas Estradas em CHICAGO: "Verificamos a conveniência de uma lei autorizando os presos do nosso Estado a trabalharem nas estradas públicas. Chegamos à convicção de que esta lei seria melhor para o preso, nossa principal preocupação. Entendemos que deveriamos lhe fornecer essa oportunidade para torná-lo mais forte e robusto, de modo que quando deixasse a prisão, em vez da tez pálida e emaciada, saisse corado e esperançoso, disposto a ganhar a vida pelo trabalho. Quando engajamos operários para qualquer serviço normal sempre contamos com um pessoal de boa força muscular. Não ha dúvida que o trabalho de estradas fortalece fisicamente $o$ indivíduo. E não é só isso: o trabalho fá-lo muitas vezes esquecer o crime praticado, e quando se lhe dá qualquer especie de recompensa - fica-lhe aquela esperança de melhores dias, que só se adquire no trabalho ao ar livre. E o dinheiro que se gasta com médico e farmácia fica reduzido ao mínimo quando os presos trabalham nas vias públicas."

"Até aqui êles trabalhavam, mas nunca deixavam a penitenciária. O seu trabalho limitava-se ás imediações da prisão, a uma distância não excedente de duas até seis milhas.

"Tinhamos receio de que eles fugissem e, como de fato, alguns desapareceram. Mais tarde começamos a cogitar de que modo, por um custo mínimo, poderiamos fazê-los trabalhar sem que êles fugissem. Lembramos, então, a adoção de uma lei estabelecendo que os presos da penitenciária, quando designados pelo diretor, pudessem saír para fóra dos muros afim de trabalhar nas estradas públicas, re- 
cebendo como recompensa a comutação de dez por trinta dias de trabalho efetivo. Temos um excelente diretor, que tem verdadeiro gôsto pelo trabalho penitenciário. Todos os presos o estimam. E' enérgico e firme; entretanto, nunca teve ocasião de aplicar o castigo máximo, tão freqüente nas prisões públicas. $E^{\prime}$ um diretor que conhece a indole e caráter de todos os presos sob a sua guarda. Começamos a empregá-los no serviço a uma distancia de 40,50 e algumas vezes até 200 milhas da Penitenciária. ESSES PRESOS NÃO SÃO VIGIADOS DURANTE O DIA. E o que é mais admiravel é que a guarda dos mesmos, durante a noite, seja feita por êles próprios. O campo está coberto de barracas sem cêrca de espécie alguma. Estão em completa liberdade.

"O diretor comunicou-me, logo depois do meu primeiro termo, a fuga de alguns, mas a perda total foi apenas de dois. Aos que vão trabalhar fora da Penitenciária, o diretor faz levantar as mãos e jurar que, em qualquer circunstância, jamais tentarão fugir e consentir que outros o façam. A simples idéia de voltar à prisão e não poder mais trabalhar ao ar livre, faz com que êles se preocupem não só com o seu futuro como com o dos seus próprios companheiros de sofrimentos. Aquele que foge perde naturalmente os privilégios a que teria direito por sua boa conduta, tendo, portanto de cumprir o máximo da pena. Colorado tem atualmente 740 presos, 400 dos quais estão trabalhando nas estradas. Se fôssemos trabalhar com pessoal livre teriamos que despender à razão de 2 dólares por trabalhador ou 800 dólares por dia ou 24.000 dólares por mês, quantia esta que fica aplicada na construção e conservação das estradas.

"Achamos, continua, que esta esperança de recompensa è de um efeito salutar para o preso, depois de concluido o seu tempo. Só o fato de poder êle obter a liberdade pelo seu próprio esforço é motivo para confiar, dali em diante, mais em si próprio do que antes. E, se dentro da prisão conseguiu êle a sua liberdade e independência, com muito mais razão fora dela. 
"Esquecia-me de dizer-vos: DURANTE O TRABALHO ELES SUBSTITUEM A VESTIMENTA CELULAR PELOS TRAJES COMUNS DAS PESSOAS LIVRES".

Respondi, por minha vez, ao Dr. José Custodio, nos seguintes termos: "A interessante conferência por V. Ex. realizada no Club de Engenharia sôbre as nossas vias de comunicação e à qual com justos encômios acaba de se referir o muito ilustre Presidente do Estado do Paraná, na sua brilhante mensagem inaugural, é digna da mais viva atenção dos poderes públicos. Mas o que mais me agradou da sua conferência foi a parte que se refere ao aproveitamento da mão de obra pessoal na abertura e construção dessas estradas. Não é de hoje que tal assunto me interessa.

Antigamente a França, inspirando-se nos exemplos de outros paises, e visando o duplo objetivo de libertar o seu território de maus elementos e de povoar as suas longínquas colônias, resolveu transportar para Caiena e Nova Caledônia os seus "forçados" — que alí seriam empregados nas obras públicas, passando, cumprida a pena, a viver como colonos livres. Èste sistema revoltou a parte sã dos habitantes daquelas colônias, que alegava ser a introdução de tão maus elementos um motivo de constante sobressalto.

Foi então que ficou resolvida a criação das SECÇốS MóVEIS, isto é, levas de condenados, que trabalhariam nas colônias até o cumprimento da pena podendo ser transferidos de uma para outra, sem jamais ficarem incorporados ao elemento colonizador permanente.

Quando ofereci a minha tese de concurso tinha eu em mente condenar o princípio anacrônico da colonização penal e afirmar as minhas preferências pela utilização da mão de obra dos condenados em trabalhos públicos onde quer que êstes existissem, convencido da ineficácia do trabalho exclusivamente carcerário. $O$ trabalho celular não indeniza o Estado dos grandes sacrifícios que faz em alojar, vestir, alimentar, educar os criminosos. Além disso, não havendo entre nós prisão perpétua, é preciso não perder de vista 
a circunstância de que o condenado destina-se a ser reincorporado à sociedade.

E' sabido que, em regra, os egressos das prisões não se ocupam, cá fóra, dos ofícios que ali aprenderam; não só porque tais ofícios como constataram os comissários das prisões inglêsas, em 1895, dão um resultado muito inferior aos que êles podem obter empregando de outra forma a sua atividade, como também porque tais ofícios ficam como que associados à idéia de pena, não os abrigando das indiscrições quasi sempre funestas dos seus antigos companheiros de prisão.

Por outro lado, a experiência, o mais autorizado dos mestres, tem revelado, no dizer do antigo Ministro italiano Gianturco "che la segnegazione cellulares continua infiacchine la fibra dei condannati, i quali non resistono piú ai lavori faticosi"

A sociedade, portanto, a prevalecer tal sistema só receberá em seu seio INVALIDOS ou INCAPAZES. Será o asilo substituindo o cárcere.

Com o trabalho ao ar livre não se dará o mesmo, porque êle desperta as energias abatidas, incita à luta corajosa pela vida estimula as aptidốes, e restitue à sociedade elementos ainda capazes de influir no seu progresso.

A Comissão Real, nomeada para o estudo das leis sôbre a servidão penal, em 1879, na Inglaterra, concluia assim o seu parecer: "Estamos convencidos de que um emprêgo severo dos presos nos trabalhos públicos tem maiores vantagens: dá-lhes hábitos da indústria, habilita-os a trabalhar a terra, a fazer escavações, a fazer estradas, a talhar as pedras, a levantar muros, fazer tijolos, a exercer toda sorte de profissões que o isolamento celular não comporta. Ademais, êstes oficios lhes permitem colocarem-se fàcilmente quando postos em liberdade; porque em geral, as pessoas empregadas nos trabalhos rudes são recrutadas sem que se faça uma minuciosa indagação dos seus antecedentes. 0 trabalho mais importante realizado pelos condenados é o que êles têm executado sob a forma de trabalhos públi- 
cos. É a prova de que êles podem restituir uma parte considerável do preço da sua manutenção.

É fora de dúvida que, mesmo no caso em que os trabalhos públicos desta natureza não produzissem um benefício pecuniário, ainda assim deveriam ser instituidos como uma parte essencial da disciplina penal, mas é certamente muito mais agradável pensar que todo trabalho produz um resultado útil.

Na Itália, o colossal trabalho de saneamento e cultivação do célebre "Agro Romano" que, desde os papas ZACCHARIaS e Adriano I. $^{\circ}$, vem preocupando a atenção dos governos, será, dentro em breve, a obra gloriosa dos condenados como o foram a da colônia de "Castiadas" da Sardenha, e a de "Tre Fontane", nos arredores de Roma.

Em 1902, quando o Ministro Giolitti justificou o projeto sôbre o emprêgo dos condenados nos trabalhos de melhoramento dos terrenos incultos e paludosos, disse: "Lo Stato ha il diritto di utilizare nel miglior modo possibile l'opera dei detenti per conpensare in parte l'erario della grave spesa che per il loro mantenimento grava il bilancio nazionale", pelo que pedia fôsse concedido ao Govêrno, "di valersi dei condennati alla reclusione e alla detenzione, qualunque sia la durata della pena che devono scontare per destinarli alla bonifica dei terreni incolti e malsani".

Era como escreveu G. Cusmano: "migliorare la terra con mezzo dell'uomo e l'uomo con mezzo della terra"

A colônia de Castiadas em uma localidade abandonada por mais de 30 anos, considerada como a peor da ilha por se achar inteiramente assolada pela malária, tornou-se mais vasta e mais importante colônia agrícola, não só da Itália como, talvez, da Europa. À fôrça de trabalho e de constância, dizia o Ministro Gianturco aquela terra estéril e paludosa, de ar pestilencial que incutia pavor aos raros habitantes das vizinhanças, acha-se transformada numa grande e bela fattaria.

$\mathrm{E}$ acrescentou: "Ne furano trascurate LE COMMUNICAZIONE STRADAL tanto utile e necessaria alle agiende 
agricola, essendosi condotta buon punto la costruzione della strada che conduce alla via provinciale per Cagliari, essendo-si iniziata la costruzione di quella che, partendo della diramazione di S. Pietro, meterà la colonia in communicazione presso la spiaggia di Carbonara, passando pel paese di villasimino, il quale isolato com'é, potrá della detta strada trarre a sua volta notevoli vantaggi."

Não foram menos notáveis os trabalhos executados na drenagem e saneamento da propriedade de "Tre Fontane", por conta e sob a direção da Soc. Agri. dos Trapistas de S. Paulo; no relatório do gerente dessa sociedade encontramse os seguintes dados:

“Dal 1. Ottobre 1881 al 30 Settembre 1882, coll'opera di 150 condannati, per i quali la Societá corrisposi la pattinta mecade giornaliera, furano eseguite importante opere di drenaggio pel proseguimento del sottosuolo, si piantarono - 25.800 arberi di eucaliptus sopra una estenzione di 22 ettari: Si cultivarono 4 ettari di legna, 5 di erba medica, 80 di grano e biada e 2 de arachidi per avi e per bestiame. Furano costruito circa di 300 metri linveari di piccoli canali in moratura per l'irrigazione dei prati; e fu costruita una strada della largura di metri 5,50, che la via Laurentina conduce alla sede della colonia rurale e venne costruita, in parte, col concorso del municipio un'altra strada larga metri 10 trá la stessa via Luarentina e la via Ostrenne, della lunghezza complessiva ai due chilometri e mezzo."

A mais aloquente, porém, das experiências foi realizada na Inglaterra. Em Portland os condenados construiram o dique e fizeram todas aquelas obras colossais de que nos dá conta E. RecLus na sua "Greografia Universal."

Em Chatem e Postsmouth encontram-se iguais trabalhos gigantescos, e que denotam um poderoso esfôrço e uma maravilhosa variedade de recursos. Todo o trabalho mecânico de construção e disposição dos materiais foi feito pelos condenados. 
Paul Bailliere em seu interessante estudo intitulado - "Serviture penale et Hard Labour", assim detalha aquelas obras:

"A Chatan, la partie ajoutée aux docks couvre un espace de 174 hectares, soit quatre fois le contenu des anciens bassins. On a utilisée la situation de l'ile S. Marie, et le canal que separait l'ile de la terre ferme a donne les trois bassins noveaux, le bassin de radoub (8 hec. 1/1), le bassin de construction ( 8 hec.) et le bassin déarment (11 hec.). Le sit des bassins est creusé à $3 \mathrm{~m}, 65$ de l'ancien sit de la reviere et il est a $9 \mathrm{~m} 63$ au desous de Pile S. Marie, Celle-ci, qui etait autre-fois de coupée par une quantité de briques, et que etait prèsque submèrge a la haute mèr, a été surlevée de $2 \mathrm{~m}, 1 / 2$ par la terre extraitée des bassins. L'ile entière a été drainée et entourée d'un quai d'embarquemente et de protection contre le mèr de plus de $3.000 \mathrm{~m}$. de largueur. Le creusement des routes, le chargement des materiaux, l'equipe des machines fixes ou mobiles, tout cela a été fait et fourni par les convits, et les murs des bassins n'ont pas moins de 17 metres de hauteur depuis la base jusqu'au sommet. A Postsmouth, des operations analogues ont été faites pour l'extension du bassin avec cette circonstance qu'il a fallu commencer par razer les vieilles fortifications. On a fait 313.242.260 briques, et la piérre de Portland queil a été necessaire d'utilizer a été prise et taillée par les convits dans la prison de Portland."

Não é só. A mão de obra dos condenados foi tambem aproveitada na construção das prisões e entre estas as de WOKING para 700 mulheres; BORSTAL para 500 homens, WORMSWOOD SCRURS para 1.052 homens. Aumentaram tambem as prisões de Chatam, Portsmouth, Varmoos, Parkhurst, Briston, e Pentoville, construindo um total de 2.558 celulas.

Parece excusado indagar se essa utilização, em tão grande escala da mão de obra penal, correspondeu à espectativa dos seus empreendedores, uma vez que se trata de inglêses. 
Entretanto não é sem utilidade conhecer os seus resultados precisos. Toda a despesa com essas obras importou apenas em 6.932.500 frs. quando confiadas a operários livres custariam 15.910.000 frs.

Pois bem, se a face econômica da questão apresenta um resultado tão eloqüente, não menos satisfatório é o resultado moral, pois que, segundo as estatísticas, a criminalidade, na Inglaterra, diminuiu em proporções surpreendentes tanto que $o$ insuspeito M. Wial, em um interessante estudo publicado na "Revue Penitenciarie", concluia:

"Nos voisins ont le droit d'être fiers de ces chiffres, que la plupart des nations leurs envient".

Há, entretanto um ponto da questão que não me parecia inteiramente resolvido. A utilização da mão de obra penal, principalmente nos grandes trabalhos públicos para os quais seria necessario o concurso de um numeroso pessoal carcerário, continuava a me parecer de difícil realização.

A conferência de V. S. pela qual fiquei sabendo o que se pratica no Estado de Colorado, da America do Norte, veiu descortinar um inexplorado campo de estudos. Realmente nada mais engenhoso do que fazer do próprio condenado o guarda de si mesmo e o árbitro da sua liberdade pela certeza que tem de que, trabalhando com resignação e portando-se convenientemente terá diminuido em proporções consideráveis a duração da sua pena.

Sem sentinela à vista, sem o degradante uniforme penitenciário, confundindo-se com o operário livre não se lembra sequer da fuga!

A idéia em si não é nova.

Já, em 1884, o insigne Beltrani Sealia propunha que para os condenados - no trabalho no qual arriscassem a vida, tivessem, em compensação, uma diminuïção de pena eqüivalente ao prolongamento da própria vida. Mas é inegável que a concepção do governador norte-americano é muito mais ampla e de efeitos mais variados. 
Se não ha falhas, como acredito, nas estatísticas do Colorado, pode o ilustre governador daquele Estado chamar a si as glórias de primeiro aplicador do sistema humanitário, com as honras de seu verdadeiro descobridor, e V. S. as de o seu principal propagandista.

Convencido da excelência dessa obra, só desejo que $V$. S. não desaníme, e que, com a tenacidade dos velhos paulistas, leve a seu termo tão simpático empreendimento, não se esquecendo de que na autorizada opinião de M. Charvein, antigo governador da Guiana Francesa, o que de mais proveitoso se tirou da mão de obra penal, naquela colônia, foi justamente a construção de uma importante rede de estradas em torno de Caiena, graças à iniciativa do Coronel LOUBERT.

A 26 de Fevereiro de 1906, O Ministro Garcia Prieto apresentou ao Senado espanhol um importante projeto de lei, inspirado pelas deliberações do Concelho Penitenciário.

Segundo êsse projeto, as penas privativas da liberdade, constantes dos arts. 106 a 110 do Codigo Penal, poderiam ser cumpridas em penitenciarias agrícolas ou instituïcões análogas, COM O TRABALHO AO AR LIVRE; os estabelecimentos penitenciários seriam localizados, de preferência, nos terrenos incultos, e o Estado, as provincias e as comunas poderiam utilizar a MÃO DE OBRA PENAL, organizando para isso estabelecimentos especiais; empregar-seiam nas colônias, de preferência, os delinquentes pertencentes à classe agrícola. $O$ sistema penal seria organizado de modo a tornar possível a libertação antecipada do condenado, transformá-lo em colono, em proprietário provisório e depois definitivo de uma pequena lavoura.

Durante a pena, o trabalho seria, no começo sem remuneração; depois seria pago por uma remuneração que se elevaria gradualmente, salvo o caso de faltas graves, em que seria até diminuïda.

As colônias serão instaladas provisória ou definitivamente, segundo elas se destinarem ao preparo dos ter- 
renos incultos destinados à população livre, ou tiverem por fim fazer sòmente executar a pena AO AR LIVRE.

Os trabalhos de adaptação e instalação serão executados pela MÃO DE OBRA PENAL. Os diretores e sub-diretores de tais estabelecimentos receberão temporáriamente uma gratificação sôbre os benefícios da exploração, correspondendo a $3 \%$.

Prossigamos ainda em alguns exemplos que nos vêm do estrangeiro.

O Concelho Superior das Prisões da França apresentou ao Congresso Penitenciário de Budapest a seguinte questão:

"Segundo que princípios poder-se-ia autorizar, e de que maneira poder-se-ia organizar a ocupação dos condenados em trabalhos de campo ou em outros trabalhos de utilidade pública, AO AR LIVRE ?

E, comenta: $03 .^{\circ}$ Congresso Penitenciário Internacional reunido em Roma, em 1885, tinha ràpidamente e sob a iniciativa de alguns dos seus oradores se ocupado já da questão de saber se era admissivel que os condenados tôssem empregados em trabalhos agrícolas ou em trabalhos públicos executados ao ar livre.

Considerando que o principio da indivídualização da pena exige que os condenados se ocupem em trabalho agrícola vinícolas ou outros executados ao ar livre, sejam empregados nos estabelecimentos penitenciários, quando possível, em trabalhos análogos às suas ocupações anteriores; considerando que, afim de prevenir os estragos que a tuberculose, ocasiona em muitos estabelecimentos penitenciários, é preciso ocupar os sentenciados em pleno ar livre, permitindo tal meio preservá-los da infecção; considerando enfim, as experiências que vários países têm feito no sentido de ocupar os condenados ao ar livre, é para desejar que o Congresso examine a fundo as condições nas quais se possa admitir e organizar o emprêgo dos condenados em trabalhos ao ar livre ou em trabalhos públicos. (Rev. Pen., 1904, pág. 28). 
Em 1902, o Sr. GiolrrTr, então Ministro do Interior, apresentou à Camara dos Deputados da Itália, o seguinte projeto de lei:

“Art. unico - E' data facoltà al Governo del Re di valersi dei condannati alla reclusione e alla detenzione, qualunque sia la durata della pena che devono scontare, per destinarli al lavoro di bonifica dei terreni incolti e malsani."

Justificando tal projeto disse o Ministro:

"Signore! - La questione relativa al lavoro dei condannati, negli stabilimenti penali forma uno dei più ardui problemi della guida carceraria e della sociologia e fu più volte oggetto di studi e di discussione nel Parlamento. Nella discussione dei bilanci del 1878 e del 1879, col voto espresso nella tornata di 7 dicembre del 1880 , nelle relazioni sui bilanci del 1883-84-85, coll'ordine del giorno del deputato Lucchini approvato nella seduta del 5 giugno 1893, la Camera si è evidentemente interessata del grave problema ed, accogliendo $\mathrm{i}$ voti espressi in molti Congressi penitenziari, ha eziandio sia raccomandato l'impiego della mano d'opera dei condannati nelle grandi opere di bonificamento. Gravi ragioni d'indole morale, fisica ed economi ca rendo necessario il lavoro dei condannati; esse è elemento indispensabile di ordine e di azione, ed è coefficiente efficacissimo per la loro redenzione morale.

Cosa ha finora provveduto l'Amministrazione Carceraria per corrispondere a si fatta necessaria ed evitare, in pari tempo, la concorrenza industriale?

Al 1. Jennaio 1902, ci trovano rinchiusi negli stabilimenti penali 22.820 condannati marchi, repartiti per specie di pene e di professione nel modo indicato nella seguinte tabella: (segue-se a tabela)

Dei suddetti 22.820 condannati erano occupati nei lavori all'aperto: 2.777 , cioè, $12,1 \%$. Nell'interno, della officine, 11.228 cioè $49,2 \%$. Inoperosi, 6.507 , cioè $28,6 \%$.

Circa la meta dei condannati presenti erano quindi occupati nelle officine interne, ma è però da tener presente che molti di essi son addetti a lavori necessarii per gli stabili- 
menti carcerari in generale, come la costruzione e manutenzione degli infissi in legno ed in ferro, la confezione e reparazione di vestiario, biancheria e calzatura, la fabbricazione di panno, lana, coperte, tessuti de canapà (cagnamo) e lino. Inoltre nelle officine degli stabilimenti penali vengano allestiti relevanti commissioni di tessuti, calzatura ed altri manufatti per conto del Ministro della guerra, della marina, della finanze, della poste, che tengano occupati molti condannati di professione tessitori, calzolai e sarti.

Compressivamente, il numero dei lavoranti nelle industrie agricola (2.777) e nelle officine interne (11.128) era, al $1 .^{\circ}$ gennaio del 1902 , di 14.005 , cioè $61,3 \%$ sul totale dei condannati presenti.

Di questi, circa il $60 \%$ erano addetti à lavori per conto dello Stato, mentre gli altri $(40 \%)$ erano adibiti a lavori per conto d'imprese o committente. Sono, quindi, in media 5.600 condannati che vengano adilisti ai lavori per conto dei privati e questa cifra basta da sola a dimostrare che LA TERNUTA CONCORRENZA DEL LAVORO CARCERARIO NON E' TALE DA RECARE SENSIBILE DANNO ALLA MANO D'OPERA LIBERA.

Il problema relativo ai lavori di dissodamento e di bonifica dei terreni incolti o malsani coll'opera dei condannati ha richiamato più. volte l'attenzione del Parlamento. La necessità di por le mani senza induggio a tali bavari di campagna è ormai universalmente riconosciuta e non è più possibile prostarse uno stato di cose che contratta colle esigenza della civiltà della igiene e della economia nazionale.

L'ostacolo opposto dalle vigente disposizione all'impiego della mano d'opera dei condannati nei lavori all'aperto potrebbe essere facilmente ruinoso, qualora il Governo, dopo di aver fatto loro espiare il primo periodo della pena con la segregazione cellulare sanzionata dell'art. 13 del Cod. Penale, ha essa facoltà di applicare ai lavori di dissoda- 
mento e benefica dei terreni incolti e malsani da parecchie migliaia di condannati alla reclusione od alla detenzione, di professioni contadini o manovali, che ora sono occupati, o si trovano disponibili per mancanza di lavoro, nell'interno degli stabilimenti di pena ordinaria.

Si tale provvedimento dovrebbe dimostrarsi in pratica non sufficiente per raggiungere lo scopo, si potranno in seguito proporre altre riforme intese ad abbreviare il periodo della segregazzione cellulare dai condannati per reclutare per essi un maggior numero di lavoranti per le opere di bonifica, conciliando così le esigenze della finanza con quelle dell'igiene e dell'umanità.

Ma quello che più importa per il momento è di conferire al Governo la facoltà di valersi dell'opera dei condannati alla recensione e detenziome dei lavori da eseguirsi in localitá malsane, facoltá che risponderebbe del resto, a quanto ebbe a verificarsi in passato, quanto sotto l'impero del vecchio Codice i condannati ai lavori forzati preferivano essere subito destinati ai lavori all'aperto.

Potrà forse opporsi da taluno che l'assegnazione su vasta scala dei condannati nella bonifica dei terreni incolti e malsani potrá rendere più facile e frequente la evasione dei detenuti o recare grave pregiudizio alla loro salute. Ma la esperienza già fatta alla colonia penale delle "Tre Fontane", ed in altre localikà, ha dimostrato che le evasioni furono in numero di malattie e di mortalità, nelle conduzione delle guardie a cavallo, l'Autorità ha un mezzo energico e rapido per opporre un efficace reparo al temuto inconveniente.

Quando poi alla possibilità di un maggior numero di malattie e di mortalità nei condannati per infezione miasmatiche i prezzi preventive e profilattile testè esperimentali con successo col concorso dell'Inspettorato Generale della Sanitá pubblica nella zona malariche affirmano che il tenuto periodo, il quale, del resto, è diviso anche dagli operai liberi del personale di amministrazione e di custodia, se non rimosso del tutto, certamente è di molto alternato. 
Signore! Il dissegno di legge, che ho l'onore di sottoporre alla vostra deliberazione, se ispira concetti; che ho dinanzi espressi, e trova il suo fundamento nel diritto, che ha lo Stato di utilizare nel migliore modo possibile l'opera dei condannati per compensare in parte l'erario della grave spese che per il loro mantenimento grava al bilancio nazionale, nel dovere che ha pura lo Stato di promuovere o facilitare le opere di bonifica dei terreni incolti e malsani, nella persuasione, infine, che il favore all'aperto costituisce uno dei mezzi più efficaci di correzione e di ravvedimento dei condannati."

Respondendo à questão dos modos de execução das penas que importasse na perda da liberdade por largo tempo, chegou-se no Congresso Penitenciário de São Petersburgo (1890), à seguinte conclusão:

“A administração penitenciária deveria organizar trabalhos, tanto quanto possivel ao ar livre e de preferência trabalhos públicos; mas com a condição indispensável de que tais trabalhos sejam instalados de maneira que os presos nunca estejam em contacto com a população livre"

O ilustre professor Jules Legrac, da Universidade de Dijon, no seu estudo sôbre os resultados da mão de obra penal na Sibéria e ilha Sakalina nos fornece os seguintes dados (Rev. Penit, 1889, pág. 559) :

$\mathrm{Na}$ ilha Sakhalina, em que as riquezas minerais são consideráveis, a mão de obra penal só tem dado maus resultados. As companhias particulares que extraïam sobretudo a hulha, tinham todas, salvo uma única renunciado ao emprêgo dos forçados que a Administração penitenciária lhes oferecia a baixo preço.

No continente, a mão de obra penal deu outros resultados e isso foi especialmente constatado por ocasião da construção do Transiberiano.

E' preciso não acreditar, como se diz por vezes que o Transiberiano foi em parte construido pela mão de obra 
penal. $\mathrm{Na}$ realidade, foram sobretudo os operários livres alí empregados, operários russos, em grande maioria até o lago Baikal, - e além, russos, italianos, siberianos, japoneses, chineses, coreanos, e alguns forçados.

Mas as experiências feitas com os forçados são muito interessantes e fornecem grande ensinamento. Em toda a parte, com effeito, em que os empresários têm empregado a mão de obra penal, têm tido o cuidado, a principio, de alimentar convenientemente os seus homens, depois de lhes pagar diretamente o trabalho realizado: OS RESULTADOS TÊM SIDO BRILHANTES.

Em 1892 na própria Sakalina, uma turma de 100 forçados preparou em 4 dias e $1 / 276.000$ dormentes de estrada de ferro, enquanto que no mesmo tempo, uma turma de 300 forçados, submettida ao regime ordinário, não preparava mais de 50.000 dormentes, inclusivé o corte de arvores. Na Sibéria as experiências foram feitas particularmente pelos forçados de Alexandrowsky, perto de Irkustk, pelos de Nortchiank, e pelos da Sakalina, empregados na linha de Oussorri.

O sistema inaugurado pelo antigo diretor d'Alexandrowsky excelente inspetor das missões M. Sipiagnine é o seguinte: oferecer o trabalho transiberiano (e o trabalho em geral) como uma recompensa em vez de o apresentar como uma obrigação.

Para fazer parte de uma turma que iria acampar na floresta, teria por certo que trabalhar muito, mas também servir bem pago e melhor nutrido, desde que se fizesse notar no presidio pela sua boa conduta e firmeza. Fazia-se assim atuar um fermento precioso de elevação moral, fazendo coincidir o interêsse com o dever, o bem estar com o trabalho.

A vigilância dos forçados (que não traziam ferros aos pés, mesmo no interior dêste presidio) era nas estradas em construção admirávelmente reduzida, quasi invisível. Mas cada turma era solidária por seus membros: se um deles fugia, toda a turma era reintegrada no presídio. Só se contaram duas evasões em 3 anos. 
Os belos resultados assim obtidos, repito, contém um ensinamento. Certamente, é preciso se dizer que não se pode sempre comparar os forçados russos, muitas vezes mais ignorantes que depravados, aos forçados franceses; mas convém dizer tambem que, se em lugar do chicote de que falam levianamente os que jamais viram de perto um forçado, que jamais deles se compadeceram, que jamais sonharam com os deveres da sociedade para com êstes mesmos que ela castiga, se, em lugar do chicote, digo eu, se fizesse agir um interêsse claro; se, em lugar de se dirigir a um rebanho de animais acorrentados, se mostrasse falar com homens capazes de um esfôrço para se elevarem, obter-se-ia, sem dúvida, alguns resultados práticos ao lado de imensas vantagens morais.

M. Sevellé, aliás, em desacôrdo sôbre certos pontos de M. Legras, tinha por sua vez informado que: “com o fim de me instruir fui a Berroughia, que não é bonita, mas para examinar de perto o ponto de partida possível de um transariano. Interroguei oficiais franceses, conversei com o meu colega Et. Flanden : êles me disseram que a linha mais necessária era a que tomasse a direção de Berroughia e Laghonal. Pois bem; faça-se essa linha e nela se empregue a mão de obra penal.

A mão de obra penal pode nos ajudar na construção de estradas de ferro, O FORÇADO NÃO FARÁ, NESTAS OPERAÇÕES LONGINQUAS, CONCORRENCIA AOS TRABALHADORES LIVRES.

E nas obras de vanguarda que o Ministro das Colônias deve empregar os condenados. Estes constituem sem duvida, um elemento inferior, mas uma vez que carregamoslhe o peso, é forçoso dêle nos servir.

Não pedimos a esses homens, à maior parte dêles mais que pequenos esfórços. Êles são bem capazes de fazer aterros, de assentar e pregar trilhos sôbre os dormentes.

Depois de se ter defendido das censuras que lhe irrogou M. Legras, M. Levellé termina: Acrescentarei agora de um modo geral (é ainda uma das minhas opiniões 
refletidas e persistentes) que os condenados deveriam ser empregados em sérias proporções na execução gradual destas emprêsas de largo folego, para as quais nós temos necessidade de braços, e ás quais deveriamos aplicar antes de tudo os nossos recursos disponiveis.

Não ha dúvida, como observou mui justamente o presidente Picor, que um forçado ou um relegado nem sempre vale um operário livre; vale, quando muito uma fração; e desde então êle não passa de uma quantidade despresível. Mas a minha tese é clara: o atelier penal, mantido pelo orçamento metropolitano deve servir para os serviços do Estado. Um dia ou outro virão ministros que darão vigor a estes princípios de correção financeira e não mais permitirão a quem quer que seja, salvo o Estado, aproveitar-se do imposto.

Será agora desagradável empregar turmas de criminosos na construção de estradas de ferro ou trabalhos análogos? Mas, o General Annenhoff, que se dignou entreter-se comigo sôbre esta questão no acampamento, de Tchordponi, contou-me que um pedaço de estrada de KIEW foi construida pela mão de obra penal.

Em nosso Maroni, a administração penitenciária, querendo ligar o centro de transportação ao de religação, empregou resolutamente os condenados para abrir uma estrada através a densa floresta de Guiana. Foi uma experiência que deu bom resultado.

Invocam-se os escrúpulos do meu antigo colega Er. Flandin e de alguns oficiais franceses, que não ousaram, sob o sol da Africa, empregar os forçados brancos em continuas corveias. Mas quando eu fui a Tuggurt verificar o que era o Sahara, recordo-me de que o General Ritter, que comandava a divisão de Constantino, usou de uma linguagem oposta.

Não foi além disso, em Moscou mesmo que o General Armankoff recrutou os soldados que com êle afrontaram as estepes desoladas e os calores sufocantes do Tukerstan, 
e sem pestanejar assentaram os trilhos e dormentes do Transcaspiano?

Não brinco com a vida ou com a saúde dos condenados; quaisquer que tenham sido as suas faltas passadas, os forçados são homens, e, sob o ponto de vista econômico êles representam, como já disse, um valor. Mas, dispondo de homens, ágeis, válidos, eu preferiria expô-los aos riscos do ar livre a embrutecê-los muitas vezes, anemiá-los lentamente nas prisões glaciais, nas celas acabrunhadas que eu vi.

Aliás contra os riscos do ar livre e até das infecções maláricas já temos valiosos recursos. Vejamos o que a respeito nos diz P. Cusmano sôbre as casas de madeira na Colônia penal de Castiadas.

O tempo é dinheiro. Uma instituição que demonstra toda a verdade do lembrado neste é aquela de - três casas de madeira ambulantes, puxadas a boi que se vêem nas remotas estepes que circundam a colônia penal de Castiadas (prov. de Cagliari) e que conduzem a longínquas paragens os trabalhadores para os melhoramentos das terras. Direi, primeiro, que destas tres casas, iguais em figura e dimensões, duas servem para a habitação de 20 condenados e uma para 4 guardas.

Cada casinha se apoia em 4 fortes rodas de madeira, que a elevam a cerca de 70,00 , e tem as seguintes dimensões: $4 \mathrm{~m} .75$ de comprimento sôbre $2 \mathrm{~m} .40$ de largura, $1 \mathrm{~m} .75$ de altura, fora a cobertura que no ponto mais alto tem 0,85 . 0 pavimento, as paredes e o teto são de madeira de speachpine), com apoios de ferro e juntas corrediças, para que o material, com o levantar ou abaixar de temperatura, não arrebente. A cobertura é de zinco. A porta de entrada colocada em um dos lados, é acessivel por meio de uma escadinha móvel, toda de madeira. O interior das casinhas dos condenados contém dez leitos dispostos quatro de cada lado e dois na frente, junto á entrada. 
Na casinha dos guardas ha quatro leitos, dois de cada lado, e no mesmo plano uma escrivaninha, um armário para medicamentos, etc.

Completam a equipagem destas habitações ambulantes uma casinha de ghise, a qual em cada parada é posta debaixo de uma cobertura de ramos; dois lampeões colocados em traves de madeira, uma ou duas juntas de bois para os necessários transportes, uma pipa com água e dois cães acorrentados.

O custo de cada casinha foi de mil liras. No verão são colocadas, na entrada e nas janelinhas, telas metalicas para impedir a entrada de mosquitos anofeles; ao mesmo tempo que são providos de capuzes e luvas os guardas e os condenados com a recomendação expressa de pôr em prática os conselhos e as prescrições do Prof. Grassi, para se defienderem contra os transmissores da malária.

E' preciso construir em região longínqua um canal ou fôsso, um caminho, fazer um enxugo de pantano, brejo ou lagoa. Com a casa fàcilmente transportável para onde convier toda a obra já se pode considerar como feita pela metade; e estando os condenados sempre perto do lugar do trabalho, evita-se a perda de tempo do vai e vem e fazemse ieconomias. E' o mesmo que se dá com a pesca de peixe coral, esponja, etc., que se faz em alto mar com a barca apropriada que, podendo servir de habitação provisória, poupa ao pescador o incômodo de voltar ao porto de partida. Em 1900, graças a tais carrinhos-habitação, começou, com o trabalho de 20 condenados, uma estrada que deverá ligar a Colônia de Castiadas com o caminho provincial Cagliari-São Vito. Esse trabalho, porém, teve que ser interrompido por causa das febres. No corrente ano pretendese prosseguir no trabalho, mesmo no vierão ou estação das febres, pela fê que se tem nos meios de defesa, contra os mosquitos, anofeles, já empregados nas casinhas ambulantes; e espera-se vencer

Terminado êste trabalho, as tres casinhas ambulantes serão talvez empregadas na abertura de um canal coletor e 
no saneamento das terras vizinhas no extremo oriente da Colônia.

A luta contra a malária, a comodidade dos carrinhos ambulantes, a obra dos condenados, reunidos como hoje em Castiadas, só terão utilidades práticas inapreciáveis, especialmente na estação estivo-outonal.

O saneamento da Sardenha e do Agro Romano não será mais um problema, em qualquer ponto se poderá cultivar a terra, qualquer que seja a estação do ano, sem receio algum e a Itália adquirirá imensas riquezas das zonas maláricas...

Nesta colônia deram-se as providências necessárias para defender os presos e os empregados contra os mosquitos, e bem assim as suas respectivas famílias.

O condenado traz o capuz de pano pintado de branco e azul, e luvas. O capuz é semelhante aos dos irmãos da Misericórdia, mas em vez de dois furos correspondentes aos olhos usam uma rede metalica de pouco mais de um decimetro quadrado. Uma outra rede do mesmo tamanho é colocada na nuca, para deixar penetrar o ar necessário á respiração. $O$ mesmo se dá com os guardas, mas o capuz dêstes, talvez para distingí-los dos presos, é de pano branco. $O$ diretor e os empregados trazem igualmente um chapéu de palha com um largo véu de tule e as mãos com as indispensáveis luvas brancas nas horas crepusculares. Dá-se o mesmo com as senhoras e senhorinhas. Estas têm o máximo cuidado consigo, mas os homens mascarados daquela forma perdem para logo a paciência e tiram tudo. Com o capuz, de fato, sente-se muito calor e súa-se abundantemente, principalmente nos dias de siroco; e nem todos se habituam com êste meio de defesa. As portas, janelas, trapeiras de todos os estabelecimentos penais existentes em Castiadas são protegidas pelas tais telas metálicas, o mesmo se dando com as casas dos funcionários.

Em suma, de Julho a Dezembro, dever-se-á ali passar a vida entre as redes metálicas, quer em casa, quer no campo. 
Os condenados ficam satisfeitos com as medidas profiláticas tomadas contra a febre malárica.

$\mathrm{Na}$ Suiça não ha uniformidade quanto à natureza do trabalho dos sentenciados, que varia de cantão a cantão.

Em Zurich, Glaris, Zug, Bale-Valle, Ganit-Gall, Grisins Tessin, Vand e Genebra, o trabalho é executado no intérior das penitenciárias; tem Berna, Lucerna, Uze, Untervald, Friburgo, Soleure, Balecampagne, Schaffhouse, Appense, l'Argovia, Thurgovir, Valois, Neuchatel, empregam-se os dois sistemas. Em Schnytz, outrora os presos eram empregados na conserva das estradas, mas como foi suprimida a Prisão os sentenciados foram transferidos para a Penitenciária de Saint-Gall.

Enfim, para não ir mais longe, lembrarei que ainda na França, o "Journal Official" de 12 de Agosto de 1898 publicou uma importante circular do Ministro das Colônias aos diversos governadores a respeito. Nela M. Fronillot mostrava preocupar-se com o desenvolvimento da agricultura e pedia um completo relatório da produção agrícola, sob o tríplice aspecto, da terra, dos capitais e dos braços. Sôbre este último ponto lhes recomendava examirar a questão da utilização da mão de obra indigena, da importada e da mão de obra penal.

Os deputados Maby e Givault apresentaram na Câmara um projeto tendo por objetivo fazer transportar para Madagascar 800 forçados, que seriam utilizados nas derrubadas das matas, construção de estradas e em todos os trabalhos de saneamento, aterros, enxugos, e os jornais daquella ilha anunciaram que a Administração estava resolvida a utilizar a mão de obra penal na abertura de um canal para o escoamento das aguas e demais necessidades que fossem aparecendo.

E a concorrência à mão de obra livre? Será justo ou apenas tolerável?

Muito teria a dizer sôbre tão palpitante assunto para demonstrar que êle em nada contraría o nosso tema, em nada compromete os termos da minha conclusão. E na 
falta de autoridade pessoal para tanto, apadrinho com os sábios e valho-me das palavras dos mais competentes.

São do notável Prof. P. Cauwes os seguintes conceitos: Neste caso não há verdadeiramente uma concorrência; o Estado age finalmente em virtude de um interêsse superior de previdência social organizando um trabalho educador tal, que permite ao liberado reentrar na ordem econômica normal. E quando o Estado produz para o seu consumo, desaparece tambem o conflito direto entre o operário livre e o condenado. Em caso algum tem o operário livre um direito adquirido a que o condenado permaneça um valor social negativo.

M. Pinbarani diz por sua vez: "Creio, pois, que a concorrência é uma sorte de concepção puramente intelectual: fala-se mais do que se vê.

Se eu sou proprietário de uma chacrinha com um pequeno jardim e uma horta onde cultivo as minhas couves, repolhos e cenouras, com o meu próprio trabalho e para o meu consumo, ninguém terá o direito de se queixar; mas se eu levasse os meus legumes ao mercado, sim, eu faria concorrência aos hortelões profissionais.

Quando nos estabelecimento penitenciários ha campos que os sentenciados cultivam e cujos produtos são empregados na sua própria alimentação, afirmo que não ha tão pouco concorrência. Não ha no país um jardineiro que tenha o direito de dizer: Vossos prisioneiros me fazem concorrência.

Não, a concorrência não é isso. Haveria concorrência se fosse levado ao mercado, ao lado dos produtos similares da mão livre, produtos da mão de obra penitenciária.

$\mathrm{O}$ inspetor geral Brunot é mais preciso. Primeiramente, diz êle, devemos nos acordar sôbre a significação exata da palavra concorrência.

Alguns têm sustentado que não haveria concorrência se os produtos do trabalho penitenciário não aparecessem no mercado. Terão razão, se se atribuì à palavra concorrência um sentido exclusivamente comercial, e se se res- 
tringir a sua significação - à "luta pela venda ou escoamento dos produtos".

Outros têm sustentado que todo o trabalho, qualquer que êle seja, -penitenciário, mecânico, etc., faz concorrência a outro trabalho. Não deixam de ter razão, também porque tomada na acepção de "luta para obtenção do trabalho disponivel", é inegável a sua existência; o consumidor que, por suas próprias mãos faz o seu calçado, priva dêste trabalho o profissional. E' preciso, pois, como sempre, fixar com precisão o sentido da palavra para nos entendermos.

Pois bem, a opinião pouco se inquieta com o preço da venda dos produtos penitenciários. Queixa-se raramente da concorrência comercial. Agita-se, sim, mas é a concorrência de trabalho; o que se critica é o abaixamento das tarifas penitenciárias.

Na França toda crítica feita ao trabalho penitenciário se resume nestas proporções: $10^{\circ}$ os presos executam uma quantidade de trabalho que seria fatalmente dos operários livres se não houvesse trabalho nas prisões; $20^{\circ}$ os salários penitenciários passam por ser superiores aos da indústria livre e por isso fazem baixar o preço da mão de obra desta.

À primeira argüição aplica-se a resposta do argumento do grande Cavour: $O$ preso antes do seu encarceramento, tinha um direito humano e natural que êle não perdeu ao transpor as portas da prisão: o direito de trabalhar.

A condenação não criou um novo operário; ela simplesmente prendeu um operário que já existia e que trabalhava fora.

À segunda argüição opõe-se, em França, a decisão do Ministro Goblet, de 15 de Abril de 1882, que fixou as regras precisas para evitar o aviltamento das tarifas da mão de obra penitenciária.

Ademais, a mão de obra penitenciária não parece assim tão vantajosa como pretendem os seus adversários, porque afirmava M. Pinbarani esta mão de obra é pouco procurada. E' extremamente dificil encontrar fabricantes, e 
quando um dêles desaparece, muitas vezes por falência, é muito dificil encontrar-se sucessores.

Embaraçar-se-iam muitas vezes os que conduzem a campanha contra as oficinas penitenciárias se lhes dissesseis: "Achais mui vantajosas estas oficinas para os vossos concorrentes: pois bem, tomai-as por vossa conta!"

Com o trabalho braçal ao ar livre, na construção e abertura de estradas, a concorrência será mìnima e dé efeitos quasi nulos para os operários livres porque ficarão ainda à disposição dêstes muitos outros serviços públicos e particulares melhor remunerados e garantidores de um futuro mais tranquilizador.

Não prosseguirei neste terreno, onde teria ainda muito que dizer para não esgotar a paciência dos meus honrados e bondosos ouvintes.

Mas não posso deixar de referir a grande satisfação que experimentei ao deparar na 2. edição do "Derecho Rural" de Eugenio Cuello Calon, ilustre catedrático da Universidade de Barcelona, edição de 1930 , as seguintes palavras referentes ao emprêgo da mão de obra penal nos trabalhos públicos:

"Esta forma de ejecution de la pena de libertad caracterizada por el trabajo al aire libre, all'aperto, como dicen los italianos presenta no pocas vantajas - ès una higienica, y saludable que la reclusion, los penados agricultores, puedem seguir praticando el trabajo a que se dedicaram llegar la hora de sua liberdad; permite la realisation de trabajos de gran valor para la economia nacional (meyoramiento del suelo, desecacion de marismas y pantanos, CONSTRUCCION DE CAMINOS; puertos, canales, etc.). Sus resultados parecem en todas partes excelentes y esta explica su adoptacion em numerosos paises. (Francia, Itália, Alemania, Dinamarca, Holanda, Belgica, Inglaterra, Hungria, Suiza, Luxemburgo, Grecia, Checoslovaquia, Yugoslavia y en los Estados Unidos y en el Canada." 
Sinto profundamente ter de confessar que, por falta de dados, ignoro o que a respeito se passa na grande maioria dos Estados da nossa querida Pátria.

Quanto a S. Paulo, na interessante Comunicação que ao 2. Congresso Pan-Americano de Estradas de: Rodagens, reunido nesta Capital, em Março de 1929, apresentou o Engenheiro Carlos Quirino Simões lê-se:

A primeira construção de estradas, feita tecnicamente, é a de S. Paulo-Campinas, CUIJOS TRINTA E DOIS PRIMEIROS KILOMETROS, da ponte sôbre o rio Tieté ao bairro dos Abreus, pouco adiante de Cayeiras, SE DEVEM AO BRAÇO PENITENCIÁRIO.

A construção FOI EXECUTADA POR TRECHOS PELOS SENTENCIADOS no periodo presidencial do Dr. Altino Arantes, sendo Secretário da Justiça o Dr. Eloy Chaves e Secretário da Agricultura (Viação e Obras Publicas) o Dr. Candido Motta. O primeiro trecho foi atacado entre a ponte sôbre o rio Tieté e Pirituba em 9 de Agosto de 1916. O segundo trecho entre Pirituba e Ribeirão Parada, FEITO COM O AUXILIO DE 84 SENTENCIADOS, teve a construção começada em 19 de Julho de 1917. O terceiro trecho, de Perús até adiante de Cayeiras, finalmente, iniciado a 15 de Agosto de 1919 , foi aquele que em $1 .^{\circ}$ de Maio de 1920 encontrou ainda em construção o novo presidente Washington Luis.

Desde então, êsse magnifico trabalho, originado do discurso com que na Câmara dos Deputados de São Paulo, a 6 de Dezembro de 1912, o Sr. Washington Luis justificou o projeto, que se converteu na lei n. ${ }^{0} 1.406$ de 26 de Dezembro de 1913 , tomou outro impulso, porque foi atacado intensamente pelo braço livre que, com mais rapidez, levou a estrada até Campinas sob a hábil direção do distinto Engenheiro Dr. Joaquim Timóteo de Oliveira Penteado.

A obra dos sentenciados, a parte que lhes toca nesse importante melhoramento não ficou esquecida. Houve até quem tivesse a idéia de erigir no ponto terminal da chamada - estrada dos sentenciados - um monumento comemorati vo dêsse grande trabalho. Fizeram-se as peças necessárias; 
transportaram-nas para o local designado, entre S. Paulo e Jundiai, mas. lá ficaram e lá estão no mesmo estado em que chegaram, isto é, desmontadas.

Porque? Porque houve também quém visse nêsse monumento uma humilhação. E' êsse, por sem dúvida, um ponto de vista muito nobre e elevado; é um respeitabilíssimo escrupulo, que só honra quem o manifestou; mas, permita-me a franqueza, o seu fundamento é da extrema fragilidade.

Como! Humilhação? Para quem, se em tal monumento não existe gravado um único nome dos muitos que fizeram o trabalho da estrada?

Não! Tal monumento não seria, tão pouco, um sinal de martírio, um angustioso calvário de infelizes; ao contrário, seria o símbolo da redenção pelo trabalho afanoso, honesto, duro talvez, mas muito compensador.

Aos libertados que por alí passaram seria o atestado imorredouro do reconhecimento social pela sua obra; aos ainda encarcerados estaria a apontar o exemplo a seguir, o caminho tão ambicionado da redenção.

Reafirmo, pois senhores, com o mesmo ardor que os anos não conseguiram amortecer, e com a mesma sinceridade - traço caraterístico de toda minha vida pública:

\section{UM DOS MELHORES EMPREGOS DA MÃO DE OBRA DOS CONDENADOS ESTA' NAS SECÇÕES MOVEIS.}

Tenho dito. 